\title{
Acatalasemic mice are mildly susceptible to adriamycin nephropathy and exhibit increased albuminuria and glomerulosclerosis
}

\author{
Keiichi Takiue ${ }^{1}$, Hitoshi Sugiyama2 ${ }^{*}$, Tatsuyuki Inoue ${ }^{1,3}$, Hiroshi Morinaga ${ }^{2}$, Yoko Kikumoto ${ }^{1}$, Masashi Kitagawa ${ }^{1}$, \\ Shinji Kitamura', Yohei Maeshima', Da-Hong Wang ${ }^{4}$, Noriyoshi Masuoka ${ }^{5}$, Keiki Ogino ${ }^{4}$ and Hirofumi Makino ${ }^{1}$
}

\begin{abstract}
Background: Catalase is an important antioxidant enzyme that regulates the level of intracellular hydrogen peroxide and hydroxyl radicals. The effects of catalase deficiency on albuminuria and progressive glomerulosclerosis have not yet been fully elucidated. The adriamycin (ADR) nephropathy model is considered to be an experimental model of focal segmental glomerulosclerosis. A functional catalase deficiency was hypothesized to exacerbate albuminuria and the progression of glomerulosclerosis in this model.

Methods: ADR was intravenously administered to both homozygous acatalasemic mutant mice $\left(\mathrm{C} 3 \mathrm{H} / \mathrm{AnLCs^{b }} C s^{\mathrm{b}}\right)$ and control wild-type mice $\left(\mathrm{C} 3 \mathrm{H} / \mathrm{AnLCs}^{\mathrm{a}} \mathrm{Cs}^{\mathrm{a}}\right)$. The functional and morphological alterations of the kidneys, including albuminuria, renal function, podocytic, glomerular and tubulointerstitial injuries, and the activities of catalase were then compared between the two groups up to 8 weeks after disease induction. Moreover, the presence of a mutation of the toll-like receptor 4 (t/r4) gene, which was previously reported in the $\mathrm{C} 3 \mathrm{H} / \mathrm{HeJ}$ strain, was investigated in both groups.

Results: The ADR-treated mice developed significant albuminuria and glomerulosclerosis, and the degree of these conditions in the ADR-treated acatalasemic mice was higher than that in the wild-type mice. ADR induced progressive renal fibrosis, renal atrophy and lipid peroxide accumulation only in the acatalasemic mice. In addition, the level of catalase activity was significantly lower in the kidneys of the acatalasemic mice than in the wild-type mice during the experimental period. The catalase activity increased after ADR injection in wild-type mice, but the acatalasemic mice did not have the ability to increase their catalase activity under oxidative stress. The $\mathrm{C} 3 \mathrm{H} / \mathrm{AnL}$ strain was found to be negative for the t/r4 gene mutation.
\end{abstract}

Conclusions: These data indicate that catalase deficiency plays an important role in the progression of renal injury in the ADR nephropathy model.

\section{Background}

The degree of oxidative stress and the severity of subsequent tissue injury may depend on an imbalance between the excessive production of reactive oxygen species and the antioxidant defense. The antioxidants include the enzymes superoxide dismutase (SOD), catalase, and glutathione peroxidase (GPX), which detoxify reactive oxygen species. Catalase (E.C.1.11.1.6) is a

\footnotetext{
* Correspondence: hitoshis@md.okayama-u.ac.jp

${ }^{2}$ Center for CKD and Peritoneal Dialysis, Okayama University Graduate School of Medicine, Dentistry and Pharmaceutical Sciences, 2-5-1 Shikata-cho, Kitaku, Okayama 700-8558, Japan

Full list of author information is available at the end of the article
}

major enzyme that catalyzes the decomposition of hydrogen peroxide $\left(\mathrm{H}_{2} \mathrm{O}_{2}\right)$ and plays a role in cellular antioxidant defense mechanisms [1]. The main reaction of catalase is the catalytic reaction $\left(2 \mathrm{H}_{2} \mathrm{O}_{2} \rightarrow \mathrm{O}_{2}+\right.$ $2 \mathrm{H}_{2} \mathrm{O}$ ), which is essential for the removal of excessive $\mathrm{H}_{2} \mathrm{O}_{2}$ and for regulating the $\mathrm{H}_{2} \mathrm{O}_{2}$ concentration [2]. Catalase limits the accumulation of $\mathrm{H}_{2} \mathrm{O}_{2}$ generated by various oxidases in tissue, and serves as a substrate for the Fenton reaction to produce the highly injurious hydroxyl radicals. Genetic defects of catalase were first documented by Takahara [3] in Japanese patients who exhibited a deficiency of blood catalase enzyme activity

\section{Biomed Central}

(c) 2012 Takiue et al; licensee BioMed Central Ltd. This is an Open Access article distributed under the terms of the Creative Commons Attribution License (http://creativecommons.org/licenses/by/2.0), which permits unrestricted use, distribution, and reproduction in any medium, provided the original work is properly cited. 
(acatalasemia) [4,5]. Subsequently, an acatalasemic mouse strain $\left(\mathrm{Cs}^{\mathrm{b}}\right)$ was established by Feinstein, Suter, and Jaroslow [6] from the progeny of x-ray-irradiated mice.

Focal segmental glomerulosclerosis (FSGS) is a common cause of nephrotic syndrome in both children and adults $[7,8]$. The clinicopathological syndrome may be classified as primary, secondary or familial. The primary defect in FSGS lies in the filtration barrier of the glomeruli. Disruption of the filtration barrier results in the loss of permselectivity, and macromolecules such as albumin are allowed to enter the urine. Chen et al. [9] reported that $\mathrm{BALB} / \mathrm{c}$ mice were susceptible to renal toxicity arising from the administration of the anthracycline antibiotic, adriamycin (ADR), with selective injury to podocytes resulting in severe proteinuria and progressive renal failure $[9,10]$. This was described as the first experimental model of FSGS in mice. The activities of antioxidant enzymes including catalase, GPX and Mn-SOD and the glutathione concentration in renal cortex were decreased by ADR nephropathy in BALB/c mice [11]. The level of nitric oxide in kidney homogenates [12], and the urinary levels of nitrite/nitrate [10] were also increased in the ADR nephropathy model. The administration of the soluble receptor for advanced glycation endproducts (AGEs) suppressed AGE generation and reactive oxygen species in the ADR nephropathy mice [13].

In the present study, we hypothesized that a defect in the antioxidant system in the form of catalase deficiency would enhance proteinuria, glomerular sclerosis, and eventually lead to the loss of renal function. This hypothesis was tested using the ADR nephropathy model, which is a well-established model of progressive FSGS, in acatalasemic mice.

\section{Methods}

\section{Experimental animal protocol}

Male wild-type mice $\left(\mathrm{C} 3 \mathrm{H} / \mathrm{AnLCs}^{\mathrm{a}} \mathrm{Cs}^{\mathrm{a}}\right)$ and male homozygous acatalasemic mutant mice $\left(\mathrm{C} 3 \mathrm{H} / \mathrm{AnLCs}^{\mathrm{b}} \mathrm{Cs}^{\mathrm{b}}\right)$ were used at the age of $8-10$ weeks. Animals were housed in cages and fed standard chow and water ad libitum. ADR $(10,15$ and $20 \mathrm{mg} / \mathrm{kg} \mathrm{BW})$ dissolved in saline was intravenously administered to both acatalasemic mutant mice and control wild-type mice [14]. In the $\mathrm{C} 3 \mathrm{H} / \mathrm{AnL}$ strain, the dose of $10 \mathrm{mg} / \mathrm{kg} \mathrm{BW}$ did not induce significant albuminuria or increase mortality (Additional file 1: Figure S1A). The $20 \mathrm{mg} / \mathrm{kg}$ BW dose resulted in a rapid increase in mortality in both groups of mice (Additional file 1: Figure $\mathrm{S} 1 \mathrm{C})$. The ADR-induced cardiotoxicity might have led to the high mortality resulting from the higher dose of ADR [15]. A total of $55.3 \%$ of the acatalasemic mice and $59.2 \%$ of the wild-type mice survived 8 weeks after the injection of $15 \mathrm{mg} / \mathrm{kg}$ BW ADR (Additional file 1: Figure S1B) with a substantial amount of albuminuria. Therefore, $15 \mathrm{mg} / \mathrm{kg}$
BW ADR was considered to be a suitable concentration to investigate the effects of a functional catalase deficiency in the ADR nephropathy model. In the control mice, the same volume of saline was injected intravenously.

Mice were divided into subgroups ( $n=6-15$ /group). Their body weight was measured at 0,4 and 8 weeks. The mice were sacrificed at 0,4 and 8 weeks after ADR administration, then their kidneys and hearts were harvested, washed with saline, blotted dry on gauze, and weighed as described previously [16,17]. The whole kidney weight and heart weight were expressed as a percentage of the body weight determined at the time the mice were sacrificed. Twenty-four hour urine samples were collected in metabolic cages every 4 weeks. Immediately before death, blood samples were drawn. The serum creatinine, blood urea nitrogen (BUN), and urinary albumin excretion (UAE) levels were measured, and the creatinine clearance $(\mathrm{Ccr})$ was calculated as described previously [16]. The experimental protocol was approved by the Ethics Review Committees for Animal Experimentation of Okayama University Graduate School (OKU-2009226).

\section{Reagents and antibodies}

Chemicals and reagents of analytical grade were purchased from Sigma Co. Ltd. (St. Louis, Missouri) or Wako Pure Chemical Ind. (Osaka, Japan) unless stated otherwise. The mouse monoclonal antibody to 4hydroxy-2-nonenal (4-HNE) was obtained from Nof Life Science (Tokyo, Japan). The N-histofine MOUSESTAIN KIT was obtained from NICHIREI BIOSCIENCES INC. (Tokyo, Japan). The catalase assay kit was obtained from Cayman (Ann Arbor, Michigan).

\section{Light and electron microscopic studies}

The kidneys were removed, fixed in 10\% buffered formalin, and embedded in paraffin. Paraffin sections (3$\mu \mathrm{m}$ thick) were stained with periodic acid-Schiff (PAS) and Masson's trichrome stain. Each tissue section was evaluated under an Olympus light microscope (Olympus, Tokyo, Japan) with a high-resolution digital camera system (Penguin 600CL; Pixera Co., Los Gatos, CA). The area of glomeruli was measured using a Microanalyzer software program (version 1.1, Japan Poladigital Co., Tokyo, Japan) [18]. Glomerulosclerosis was quantified using the percentage increase in the relative mesangial matrix area (the PAS-positive area within the glomerulus divided by the glomerular capillary area; high magnification). All mean values were calculated from 10 glomeruli. Electron microscopy was performed for the mouse kidney specimens as described previously $[16,17]$. A quantitative analysis was performed to count the number of podocyte foot processes per $10 \mu \mathrm{m}$ of glomerular basement membrane in each glomerulus by 
electron microscopy. The mean number of podocyte foot processes was defined as the effacement score. The area of interstitial fibrosis in the cortex was evaluated with Masson's trichrome as described previously [19], with some modifications. Under low magnification, the number of casts in five randomly selected non-overlapping fields from the cortical region was counted and averaged as the cast score.

\section{Immunohistochemistry}

To detect lipid oxidation products, paraffin sections (3$\mu \mathrm{m}$ thick) were stained using an N-histofine MOUSESTAIN KIT as described previously [20]. A mouse monoclonal antibody to 4-HNE was used as the primary antibody (1:100 dilution). Under low magnification, five randomly selected non-overlapping fields from the cortical region were analyzed. The 4-HNE positive areas that were stained in brown were picked up on digital images, and the percentage of the 4-HNE positive area relative to the whole area of the field was calculated (\% area).

\section{Renal catalase activity}

Kidney samples were stored in a $-80^{\circ} \mathrm{C}$ freezer until being assayed. The catalase activity in each kidney was determined by an ELISA using a catalase assay kit [21]. All procedures were performed according to the manufacturer's instructions.

Toll-like receptor-4 gene (T/r4) mutation analysis in exon

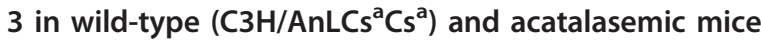
(C3H/AnLCs ${ }^{b} \mathrm{Cs}^{\mathrm{b}}$ )

The detection of the Tlr4 mutation was performed using nested-PCR as described previously [22]. The nested PCR for detection of the missense mutation, a $\mathrm{C}$ to $\mathrm{A}$ transversion (Pro712His), which was reported in the $\mathrm{C} 3 \mathrm{H} / \mathrm{HeJ}$ mouse strain [23], was performed using the primers shown in Additional file 2: Table S1. The primers TLR4-ex3-F and TLR4-ex3-R were used for direct sequencing of DNA extracted from the mouse kidneys.

\section{Statistical analyses}

The data were shown as the means \pm SE. The normal distribution and homogeneity of variance were checked, and logarithmic transformations were made for the variables if needed. Multiple comparisons between groups were made by Scheffe's test or the Steel-Dwass test. A Kaplan-Meier analysis and the Log-Rank statistic were used to explore the effects of ADR in both groups of mice. The statistical analysis was performed using the Excel add-in software Statcel 2 program (OMS, Tokyo, Japan) or the JMP 9 software program (SAS Institute Inc., Cary, North Carolina). $\mathrm{P}<0.05$ denoted the presence of a statistically significant difference.

\section{Results}

Changes in body weight, kidney weight, and heart weight in the mouse ADR nephropathy model

The ADR nephropathy model has been extensively studied in animals of the BALB/c background. Therefore, we first tried to characterize this model in our mouse strains. The body weight, relative kidney weight and relative heart weight were similar between the groups at the start of the experiment (Table 1). Both groups of mice lost a similar amount of body weight by 8 weeks after ADR administration. However, the relative kidney weight in acatalasemic mice was lower at 8 weeks than that in wild-type mice after ADR administration. The relative heart weights were similar for both groups during the experimental period.

The increase in albuminuria is significantly accelerated in acatalasemic mice after ADR administration

To evaluate the effect of acatalasemia on ADR-induced alterations of biological functions, we measured the parameters of renal function (Table 1) and UAE (Figure 1 ). The basal levels of BUN and Ccr were not significantly different between the wild-type and acatalasemic mice. In both groups, the renal function did not significantly change during the experimental period. However, UAE was elevated significantly after ADR administration at weeks 4 and 8 in both groups. The UAE in the acatalasemic mice was higher than that in wild-type mice after ADR administration at week 4 .

Table 1 The metabolic and laboratory data of the mice

\begin{tabular}{|c|c|c|c|}
\hline Group & 0 week & 4 week & 8 week \\
\hline \multicolumn{4}{|l|}{ Body weight (g) } \\
\hline Wild ADR & $29.1 \pm 0.50$ & $29.6 \pm 0.41$ & $24.8 \pm 0.97^{a, c}$ \\
\hline Acatalasemic ADR & $28.0 \pm 0.40$ & $28.2 \pm 0.31$ & $24.1 \pm 0.84^{b, d}$ \\
\hline \multicolumn{4}{|c|}{ Relative kidney weight (\% of body wt) } \\
\hline Wild ADR & $1.68 \pm 0.05$ & $1.67 \pm 0.04$ & $1.70 \pm 0.13$ \\
\hline Acatalasemic ADR & $1.94 \pm 0.04$ & $1.66 \pm 0.04$ & $1.30 \pm 0.08^{b, c, e}$ \\
\hline \multicolumn{4}{|c|}{ Relative heart weight ( $\%$ of body wt) } \\
\hline Wild ADR & $0.38 \pm 0.02$ & $0.48 \pm 0.02$ & $0.48 \pm 0.05$ \\
\hline Acatalasemic ADR & $0.43 \pm 0.03$ & $0.52 \pm 0.01$ & $0.40 \pm 0.03$ \\
\hline \multicolumn{4}{|c|}{ Blood urea nitrogen (mg/dl) } \\
\hline Wild ADR & $23.8 \pm 1.29$ & $26.4 \pm 0.77$ & $25.6 \pm 4.31$ \\
\hline Acatalasemic ADR & $26.0 \pm 1.02$ & $26.7 \pm 2.56$ & $32.6 \pm 4.16$ \\
\hline \multicolumn{4}{|c|}{ Creatinine clearance $(\mu \mathrm{l} / \mathrm{min} / \mathrm{g}$ BW) } \\
\hline Wild ADR & $2.68 \pm 0.81$ & $3.80 \pm 0.99$ & $2.10 \pm 0.77$ \\
\hline Acatalasemic ADR & $3.53 \pm 1.27$ & $3.21 \pm 1.13$ & $1.61 \pm 0.61$ \\
\hline
\end{tabular}

The values are the means \pm SE of 6 to 43 animals in each group Wild, wild-type mice; Acatalasemic, acatalasemic mice; ADR, adriamycin

${ }^{a} \mathrm{P}<0.05$ vs. week 0 in the same group

${ }^{b} \mathrm{P}<0.01$ vs. week 0 in the same group

${ }^{c} \mathrm{P}<0.05$ vs. week 4 in the same group

${ }^{d} P<0.01$ vs. week 4 in the same group

e $\mathrm{P}<0.01$ vs. the wild-type ADR group at the same time point 


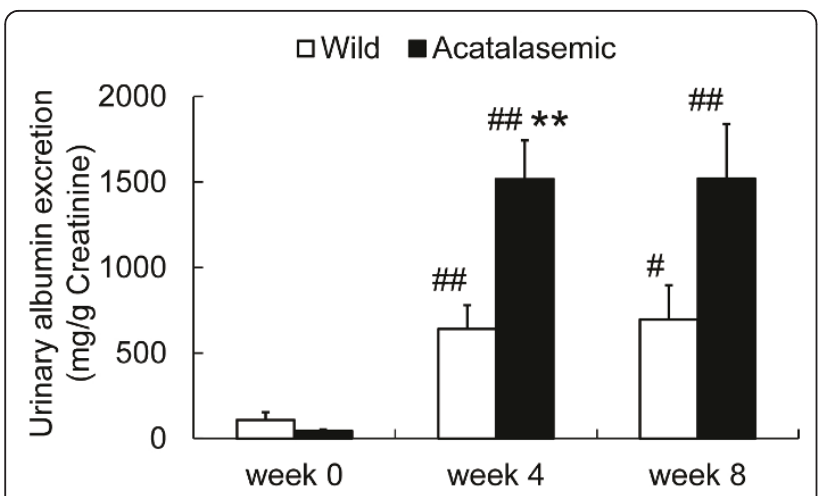

Figure 1 The changes in urinary albumin excretion (UAE) in wild-type (open bars) and acatalasemic mice (closed bars). The UAE significantly increased in both groups at 4 and 8 weeks after Adriamycin (ADR) administration. The elevation of UAE in acatalasemic mice was higher at 4 weeks after ADR administration compared to that in wild-type mice. Each column consists of the means \pm SE. $N=9$ to 39 animals/group. ${ }^{*}: \mathrm{P}<0.01$ vs. wild-type ADR mice at the same time point. \#: $p<0.05$ vs. week 0 in the same group. \#\#: $p<0.01$ vs. week 0 in the same group.

\section{Acatalasemia accelerates glomerulosclerosis and tubulointerstitial fibrosis}

At the start of the experiment, no histological abnormalities of the glomeruli were observed at the light microscopic level in either group (Figure 2A and 2B). The glomeruli in the acatalasemic mice were significantly hypertrophied after ADR administration at week 4 (Figure $2 \mathrm{D}$ and $2 \mathrm{G}$ ). In the acatalasemic mice, glomerulosclerosis developed earlier than in wild-type mice, and it was significantly increased at week 4 compared with that in wild-type mice after ADR administration (Figure $2 \mathrm{C}$ through $F$ and $2 H$ ). A decrease in the effacement score of the podocyte foot processes was observed in glomeruli of both groups of mice (Additional file 3: Figure $\mathrm{S} 2 A$ through $F$ ), however, there were no significant changes in the effacement scores in either group at week 4 and 8 after ADR administration (Additional file 3: Figure S2G). Tubulointerstitial fibrosis developed significantly in the kidneys of acatalasemic mice group (Figure 3B, D, F and 3G) at 4 and 8 weeks after ADR administration, with significant cast formation noted at week 4 (Figure 3H). The tubulointerstitial changes in the kidneys of wild-type mice after ADR administration were not statistically significant compared to that of acatalasemic mice (Figure 3A, C, E, G and 3H).

\section{Acatalasemia enhances the accumulation of lipid peroxides in the kidneys of the ADR nephropathy model mice}

Modification of proteins and lipids by oxidative stress is believed to play a central role in a variety of biological activities, such as apoptosis and extracellular matrix expansion $[18,24,25]$. The major content of the cell membrane is lipids, and thus, lipid peroxidation may cause renal injury. We next examined whether acatalasemia influenced the lipid peroxidation products in the tubulointerstitial compartment of the kidneys in ADR nephropathy. At the start of the experiment, there was almost no accumulation of 4-HNE in the kidneys of either group (Figure $4 \mathrm{~A}$ and $4 \mathrm{~B}$ ). There was an increase in the 4-HNE antibody labeling of various patches in the tubules of kidneys after ADR administration in both groups (Figure $4 \mathrm{C}$ through $4 \mathrm{~F}$ ). The degree of 4-HNE accumulation in the cortex of the kidneys in acatalasemic mice was significantly higher than that in wild-type mice 8 weeks after ADR administration (Figure 4G).

\section{The catalase activity in acatalasemic ADR nephropathy} kidneys did not significantly change

The maintenance of tissue homeostasis requires an appropriate balance between oxidants and antioxidants. Two major antioxidant enzymes, catalase and GPX, are physiologically involved in the detoxification of $\mathrm{H}_{2} \mathrm{O}_{2}$, and thus protect tissues from oxidant-mediated injury. Therefore, we next examined the catalase activity in acatalasemic ADR kidneys. Although the renal catalase activity of the wild-type mice was increased significantly at week 4 after ADR administration, that from the acatalasemic mice was decreased compared with wild-type mice at the start of the experiment, and remained low during the entire experimental period (Figure 5). Since high catalase levels are found in erythrocytes, we compared the catalase activity between saline-perfused and unperfused kidneys after the removal of residual blood. The catalase activity of the perfused kidney was $6.0 \pm$ $0.2 \%$ lower than that of the unperfused kidney [17]. Since the catalase activity was enhanced in wild-type mice 4 weeks after ADR administration and was thought to contribute to reactive oxygen elimination, we investigated the levels of other renal antioxidant enzymes, such as GPX and SOD, in wild-type or acatalasemic mice 4 weeks after ADR administration. The activity levels of GPX and SOD did not show any remarkable changes in either of the groups of mice (data not shown). Since SOD catalyzes the conversion of the superoxide anion radical to $\mathrm{H}_{2} \mathrm{O}_{2}$ and $\mathrm{O}_{2}$, it has been suggested that the level of production of ROS mediated by SOD may be similar in the ADR-nephropathy kidneys in both groups.

\section{Toll-like receptor-4 mutation analysis}

To examine the background of the mouse strains, we performed a mutation analysis of Tlr4 exon 3. Tlr4 did not show a $\mathrm{C}$ to $\mathrm{A}$ transversion due to a missense mutation in the $\mathrm{C} 3 \mathrm{H} / \mathrm{AnL}$ mouse strain, which was reported to be present in the $\mathrm{C} 3 \mathrm{H} / \mathrm{HeJ}$ strain (Additional file 4: Figure S3) [23]. 

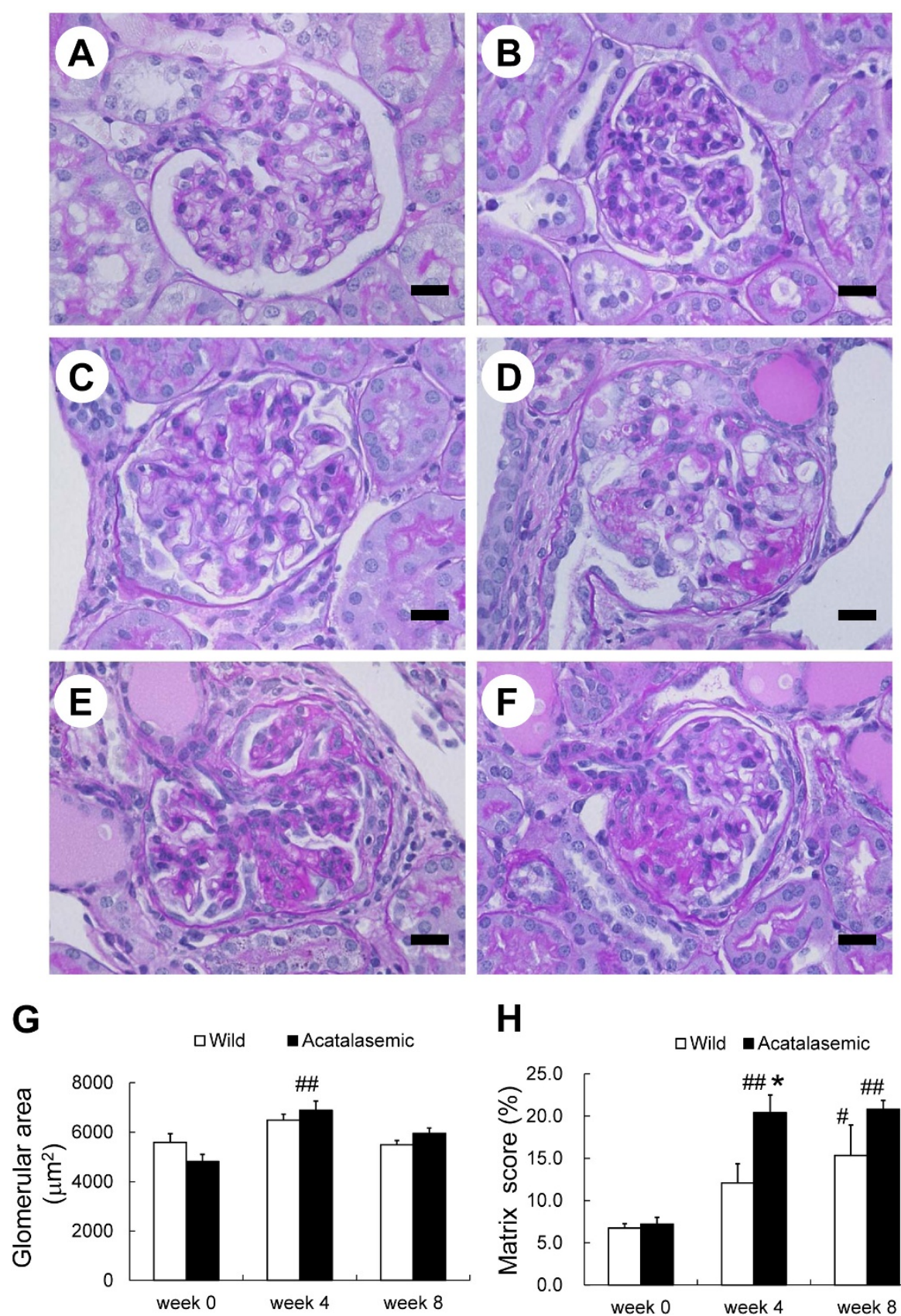

H

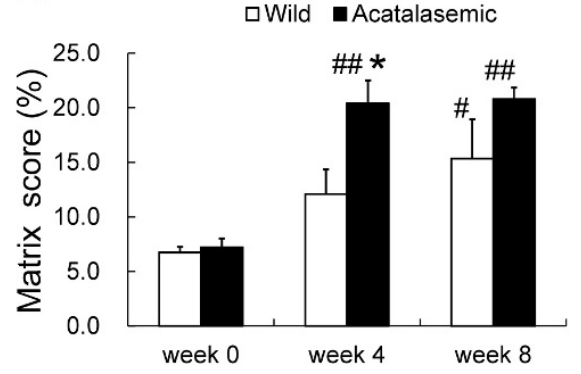

Figure 2 The renal histology in wild-type and acatalasemic mice. Light micrographs of a glomerulus of wild-type $(A, C$ and $E)$ and acatalasemic ( $B, D$ and $F$ ) glomeruli at 0,4 and 8 weeks after adriamycin (ADR) administration are shown. The week 0 glomeruli were microscopically normal. Note that the segmental sclerosis is significant in both acatalasemic and wild-type glomeruli at the later time points. The glomerular area $(G)$ and sclerosis index $(H)$ of wild-type (open bars) or acatalasemic (closed bars) mice are also shown. $A$ through $F$ : periodic acid-Schiff stain. Scale bars: $20 \mu \mathrm{m}$ ( $A$ through $F$ ). $G$ and H: Each column shows the means \pm SE. $N=6$ to 15 animals/group. *: P $<0.05$ vs. wildtype ADR mice at the same time point. \#: $p<0.05$ vs. week 0 in the same group. \#\#: $p<0.01$ vs. week 0 in the same group.

\section{Discussion}

In the present study, acatalasemic mouse strains deficient in catalase activity were used as an animal model. These mice were found to be more susceptible to functional and morphological alterations in the kidneys induced by adriamycin than wild-type mice. The level of albuminuria and glomerulosclerosis in the acatalasemic mice after adriamycin injection was significantly higher than that in the wild-type mice. The renal catalase activity in these mice remained low, without compensatory 

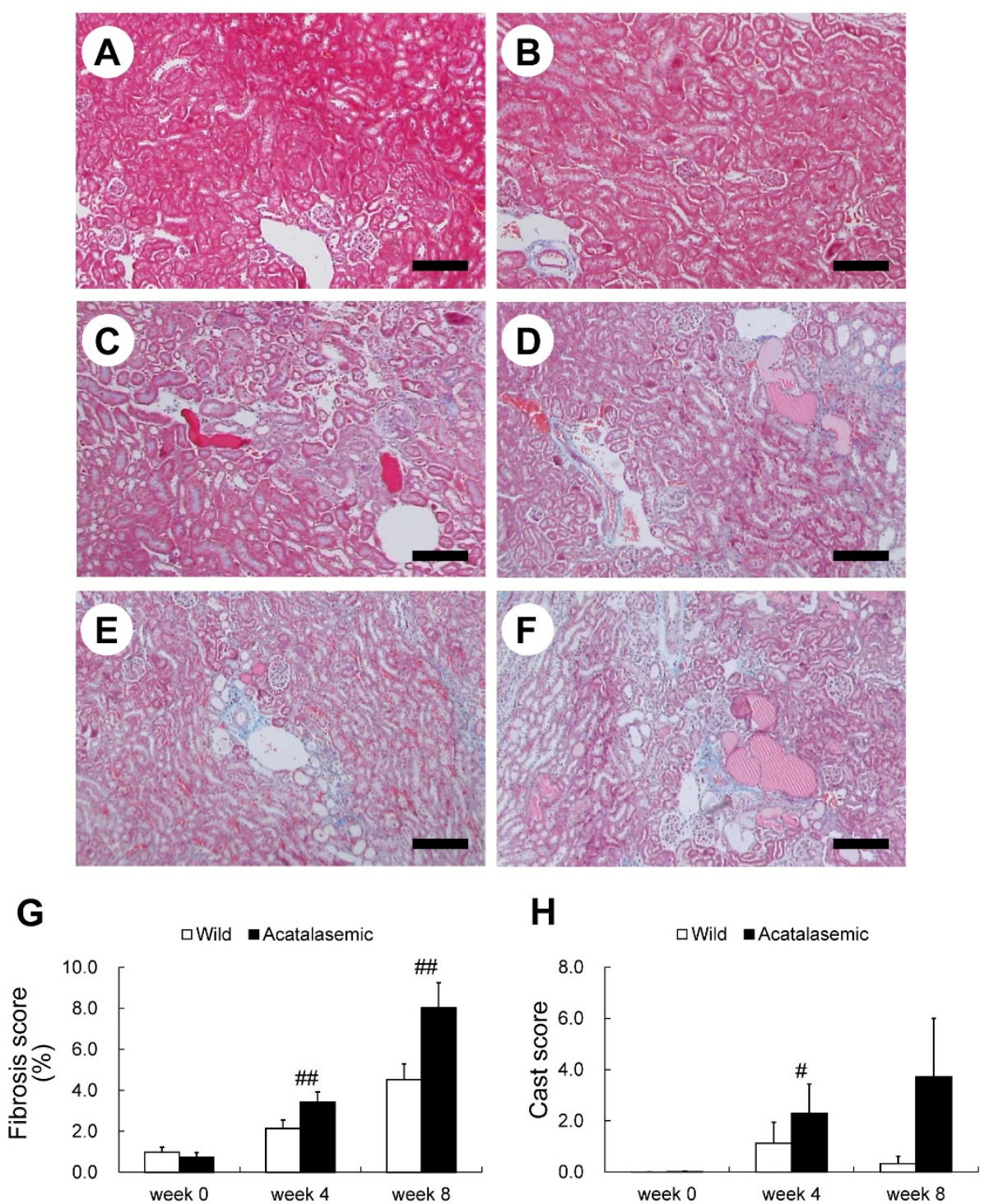

Figure 3 Light micrographs of the wild-type $(A, C$ and $E)$ and acatalasemic $(B, D$ and $F)$ kidney cortex at 0,4 and 8 weeks after adriamycin (ADR) administration are shown. Note that interstitial fibrosis significantly developed in the kidneys of the acatalasemic mice. The fibrosis scores $(G)$ and cast scores $(H)$ of wild-type (open bars) and acatalasemic (closed bars) mice are also shown. A through F: Masson's trichrome stain. Scale bars: $200 \mu \mathrm{m}$ (A through F). $\mathrm{G}$ and H: Each column includes the means \pm SE. N $=6$ to 15 animals/group. \#: $p<0.05$ vs. week 0 in the same group. \#\#: $p<0.01$ vs. week 0 in the same group.

upregulation of GPX or SOD. Collectively, these data suggest that the increased ROS, particularly the hydroxyl radical, resulting from the reduction of catalase activity, may be involved in the acceleration of glomerulosclerosis found under acatalasemic disease conditions.

Although some rat strains show complete susceptibility to ADR, most mouse strains do not. Zheng et al. showed that AKR/J, C3H/HeJ, CBA/J, C57BL/10J, LP/J, SWR/J, SJL/J, and 129S6/SvEvTac mice were resistant to ADR nephropathy, whereas 129S1/SvImJ and BALB/ cByJ mice were susceptible $[26,27]$. They also showed that the susceptible allele for the adriamycin was present in the DOXNPH locus [28]. We did not confirm whether this allele is present in the $\mathrm{C} 3 \mathrm{H} / \mathrm{AnL}$ mouse strain. Instead, we performed a mutation analysis of the TLR4 gene, because it has been thought that TLR4 is involved in progressive renal fibrosis [29]. TLR4 is considered to be the critical component of the LPS receptor complex. In 1998, a point mutation in the TLR4 gene was found to be the molecular basis of the LPS hyporesponsiveness in $\mathrm{C} 3 \mathrm{H} / \mathrm{HeJ}$ mice [23]. The $\mathrm{C} 3 \mathrm{H} / \mathrm{AnL}$ mice used in the present study did not have this mutation. Therefore, ADR induced mild renal fibrosis in both groups, although the degree of 

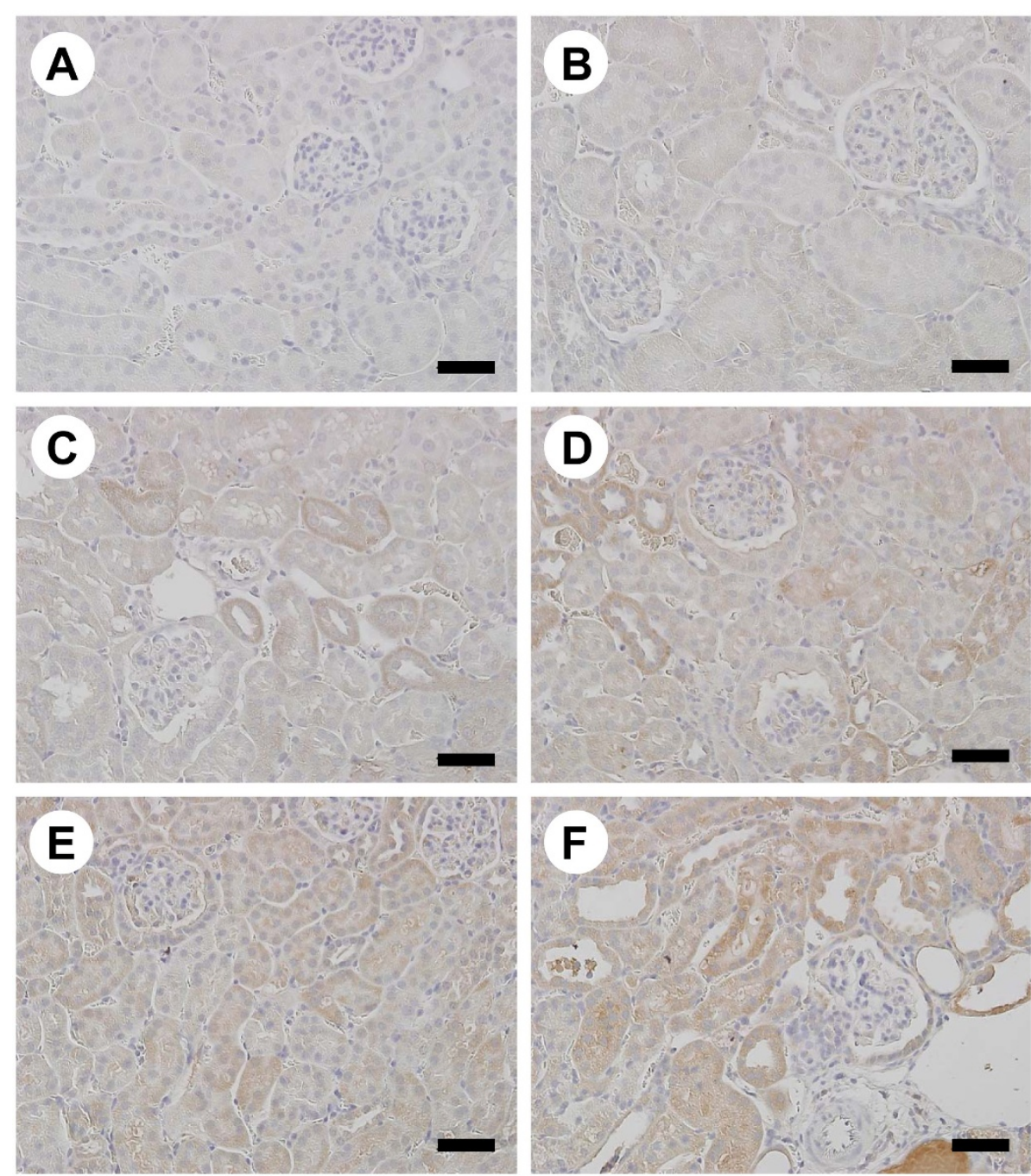

G

$\square$ Wild $\square$ Acatalasemic

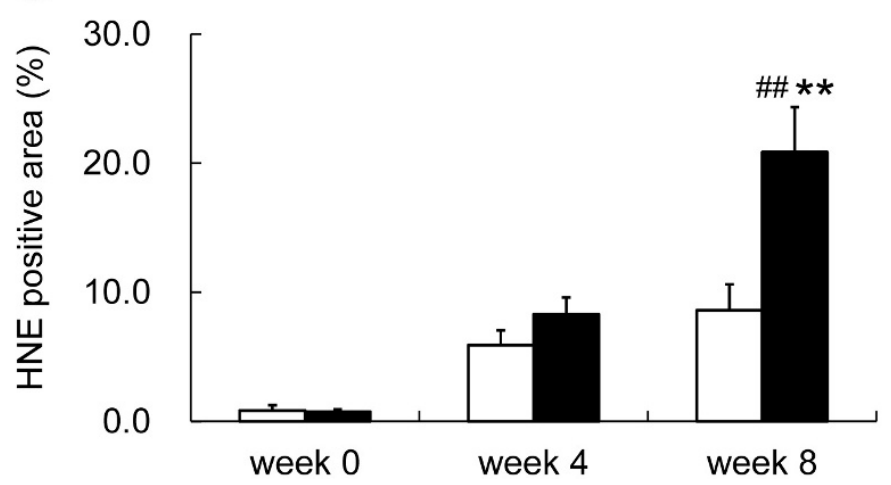

Figure 4 Immunohistochemical staining of 4-hydroxy-2-nonenal (4-HNE). Wild-type $(A, C$ and $E$ ) and acatalasemic $(B, D$ and $F)$ cortex samples at 0, 4 and 8 weeks after adriamycin (ADR) administration are shown. The 4-HNE positive areas (G) of wild-type (open bars) or acatalasemic (closed bars) mice are also shown. Scale bars: 50 m (A through F). G: Each column shows the means \pm SE. N $=6$ to 8 animals/ group. **: $P<0.01$ vs. wild-type ADR mice at the same time point. \#\#: $p<0.01$ vs. week 0 in the same group. 


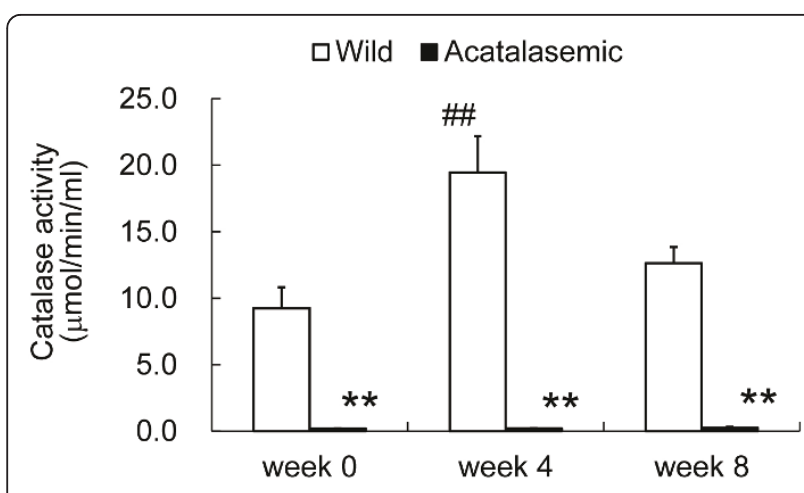

Figure 5 The renal catalase activities in wild-type (open bars) and acatalasemic mice (closed bars). Each column consists of the means \pm SE. $N=5$ to 10 animals/group. *: $\mathrm{P}<0.05$ vs. wild-type adriamycin (ADR) mice at the same time point. ${ }^{* *}: P<0.01$ vs. wildtype ADR mice at the same time point. \#\#: $p<0.01$ vs. week 0 in the same group.

interstitial fibrosis was only significant in the acatalasemic mice.

ADR induced severe albuminuria, thus leading to values ranging from 23 to $226 \mathrm{mg} / \mathrm{mgCr}$ in $\mathrm{BALB} / \mathrm{cj}$ mice and a value of $0.04 \mathrm{mg} / \mathrm{gCr}$ in B6/D2 mice [30]. In our study, ADR induced relatively mild albuminuria, with $0.6 \mathrm{mg} / \mathrm{mgCr}$ in wild-type and $1.5 \mathrm{mg} / \mathrm{mgCr}$ in acatalasemic mice. The $\mathrm{C} 3 \mathrm{H} / \mathrm{AnL}$ mouse strain is considered to have mild sensitivity to ADR. A single dose of ADR $(9.5 \mathrm{mg} / \mathrm{kg} \mathrm{BW})$ brought about $40 \%$ segmental glomerulosclerosis in the BALB/c mouse strain in a previous study [31]. The wild-type mice which we used in this study had only $15 \%$ segmental glomerulosclerosis at week 8 after administration, while the acatalasemic mice had $20 \%$ glomerulosclerosis at week 8 . This indicates that when the catalase activity is decreased, the resistance to ADR is diminished, and segmental glomerulosclerosis is induced. The number of foot processes of the podocytes did not differ between the mouse groups, indicating that the foot process effacement of the podocytes was affected to a similar degree in both mouse groups. The discrepancy between the level of albuminuria and the degree of foot process effacement may be due to the fact that this evaluation procedure compares only the surviving podocytes in the unsclerosed glomerulus.

Noiri et al. previously investigated the percentage of cortical interstitial volume in the ADR model [19], and Turnberg et al. evaluated tubulointerstitial injury, including cast formation [32]. We evaluated the presence of tubulointerstitial injury in similar analyses, and found significant tubulointerstitial injury only in the acatalasemic mice. The fact that acatalasemia exacerbates pulmonary fibrosis in bleomycin-induced lung injury [33] and chlorhexidine gluconate-induced peritoneal fibrosis [34] was already demonstrated. In this study, we showed that acatalasemia exacerbates renal fibrosis in a murine FSGS model.

The overexpression of catalase prevented albuminuria and interstitial fibrosis in the angiotensinogen transgenic mice [35]. In our study, the deficiency of catalase accelerated the albuminuria and glomerular sclerosis in the ADR nephropathy model. These data suggest that reactive oxygen species may contribute to progressive renal injury. Injac et al. reported that the activity of catalase, which detoxifies hydrogen peroxide to $\mathrm{H}_{2} \mathrm{O}$, was increased after ADR administration in rats [36]. We measured the catalase activity in the whole kidneys of wild-type mice, and found that its level increased after ADR administration. Therefore, the differences in the albuminuria and the degree of glomerulosclerosis between wild-type and acatalasemic mice may be due to the significant difference of catalase activity in kidneys in these mice and the inability of the acatalasemic mice to increase catalase activity under oxidative stress.

Sheerin et al. reported that ADR-injected mice that died in the complement protein $\mathrm{C} 3+/+$ group at 6 weeks had a high serum urea level prior to death [37]. In the current study, all mice survived for at least 4 weeks after the injection of $15 \mathrm{mg} / \mathrm{kg} \mathrm{BW}$ ADR; however $44.7 \%$ of the acatalasemic mice and $40.8 \%$ of the wild-type mice died 8 weeks after the administration of ADR. These mortality rates were not significantly different between the two groups (Additional file 1: Figure $\mathrm{S} 1 B$ ). Since the incidence of albuminuria was analyzed in all of the mice that had survived at 8 weeks, but histological studies were not performed in more than half of the mice that survived at 8 weeks, bias might have been introduced into the analysis. We did not take blood samples or evaluate the serum urea levels in ADR-treated mice that died just before the end of the 8 weeks in this study. In addition, the administration of ADR can cause cardiotoxicity [15] and gastrointestinal toxicity in mice [38], however we could not confirm these toxicities in our experiments.

Acatalasemia is a rare human disease [3,39]. It is unknown whether albuminuria and glomerulosclerosis are related to low catalase activity in humans, although the total antioxidant capacity is correlated with albuminemia, and inversely correlated with proteinuria and anti-DNA antibodies in subjects with lupus nephritis [40]. In addition, apoptosis, which is thought to be related to oxidative stress, correlated with the immunoserological activities of lupus nephritis [41] and idiopathic early FSGS [42]. However, the mechanism(s) by which oxidative stress influences human renal disease is largely unknown. Further studies are needed to elucidate whether and how a low catalase activity in humans 
influences either albuminuria or glomerulosclerosis associated with kidney diseases.

\section{Conclusions}

We herein demonstrated that ADR induced more albuminuria and glomerulosclerosis in catalase-deficient mice. Treatment with catalase supplementation may contribute to the suppression of progressive renal injury with proteinuria and glomerulosclerosis.

\section{Additional material}

Additional file 1: Figure S1 The survival rate in the wild-type (open square) or acatalasemic mice (closed square) used for the adriamycin nephropathy model. (A) The mice treated with a dose of $10 \mathrm{mg} / \mathrm{kg} B W(\mathrm{~N}=24$, in each group). (B) The mice treated with a dose of $15 \mathrm{mg} / \mathrm{kg}$ BW ( $\mathrm{N}=46$ to 66 animals/group). $P=0.56$. (C) The mice treated with a dose of $20 \mathrm{mg} / \mathrm{kg} \mathrm{BW}(\mathrm{N}=3$, in each group). $\mathrm{P}=0.43 . \mathrm{n}$. s., not significant.

Additional file 2: Table S1 Primers used for direct sequencing. Additional file 3: Figure $S 2$ Electron micrographs of wild-type ( $A, C$ and $E$ ) and acatalasemic ( $B, D$ and $F$ ) kidneys are shown. The glomeruli 8 weeks after treatment with the vehicle control showed almost normal foot processes ( $A$ and $B$ ). Note the increased podocyte foot process effacement of both kidneys (arrowheads in $C$ through $F$ ) at 4 ( $C$ and $D)$ and 8 ( $E$ and $F$ ) weeks after adriamycin administration. The effacement score of the podocytes $(G)$ of wild-type (open bars) or acatalasemic (closed bars) mice are also shown. Scale bars: $1.0 \mu \mathrm{m}$. Each column shows the means \pm SE. $N=5$ to 6 glomeruli/group. \#\#: $p<0.01$ vs. vehicle control at 8 weeks in the same group.

Additional file 4: Figure S3 The results of the toll-like receptor-4 gene (T/r4) mutation analysis in exon 3 in wild-type $(\mathrm{C} 3 \mathrm{H} /$ AnLCsaCsa) and acatalasemic mice (C3H/AnLCsbCsb). (A) A diagram of exon 3 along with primer designs for PCR and the sequences. (B) The results of the sequence analysis. Tr 4 does not show the missense mutation, a C to A transversion (Pro712His), which was reported in the $\mathrm{C} 3 \mathrm{H} / \mathrm{HeJ}$ mice strain.

\section{Acknowledgements}

We thank Ms. T. Hashimoto, Y. Sato and S. Kameshima for their valuable technical assistance and Ms. Ariyoshi for maintaining the acatalasemic mouse strains. We also are grateful to Dr. H. A. Uchida for his excellent advice on the tru mutation analysis. A portion of this study was supported by a Grant-in-Aid for Progressive Renal Diseases Research, Research on Intractable Disease, from the Ministry of Health, Labor and Welfare of Japan.

\section{Author details}

'Department of Medicine and Clinical Science, Okayama University Graduate School of Medicine, Dentistry and Pharmaceutical Sciences, 2-5-1 Shikatacho, Kita-ku, Okayama 700-8558, Japan. ${ }^{2}$ Center for CKD and Peritoneal Dialysis, Okayama University Graduate School of Medicine, Dentistry and Pharmaceutical Sciences, 2-5-1 Shikata-cho, Kita-ku, Okayama 700-8558, Japan. ${ }^{3}$ Center for iPS Cell Research and Application, Kyoto University, Kyoto, Japan. ${ }^{4}$ Public Health, Okayama University Graduate School of Medicine, Dentistry and Pharmaceutical Sciences, 2-5-1 Shikata-cho, Kita-ku, Okayama 700-8558, Japan. ${ }^{5}$ Department of Life Science, Okayama University of Science, 1-1, Ridai-cho, Kita-ku, Okayama 700-0005, Japan.

\section{Authors' contributions}

$K T$ designed the study, carried out the experiments, undertook the data analysis and wrote the manuscript. HS and HM conceived of the study, and participated in its design and coordination, and helped to draft the manuscript. TI, HM, YK and MK participated in experimental sampling. SK and YM undertook the data analyses. NM cooperated with the enzyme activity measurement. DW and KO helped with the animal experiments. All authors read and approved the final manuscript.

\section{Competing interests}

The authors declare that they have no competing interests.

Received: 22 October 2011 Accepted: 25 March 2012

Published: 25 March 2012

\section{References}

1. Chance $B$, Sies $H$, Boveris A: Hydroperoxide metabolism in mammalian organs. Physiol Rev 1979, 59(3):527-605.

2. Zamocky $M$, Furtmuller $P G$, Obinger C: Evolution of catalases from bacteria to humans. Antioxid Redox Signal 2008, 10(9):1527-1548.

3. Takahara S: Progressive oral gangrene probably due to lack of catalase in the blood (acatalasaemia); report of nine cases. Lancet 1952, 2(6745):1101-1104

4. Ogata M: Acatalasemia. Hum Genet 1991, 86(4):331-340.

5. Ogata $\mathrm{M}$, Wang $\mathrm{DH}$, Ogino $\mathrm{K}$ : Mammalian acatalasemia: the perspectives of bioinformatics and genetic toxicology. Acta Med Okayama 2008, 62(6):345-361.

6. Feinstein RN, Suter $H$, Jaroslow BN: Blood catalsase polymorphism: some immunological aspects. Science 1968, 159(815):638-640.

7. Haas $M$, Spargo BH, Coventry S: Increasing incidence of focal-segmental glomerulosclerosis among adult nephropathies: a 20-year renal biopsy study. Am J Kidney Dis 1995, 26(5):740-750.

8. Lavin PJ, Gbadegesin R, Damodaran TV, Winn MP: Therapeutic targets in focal and segmental glomerulosclerosis. Curr Opin Nephrol Hypertens 2008, 17(4):386-392.

9. Chen $A$, Wei $C H$, Sheu LF, Ding SL, Lee WH: Induction of proteinuria by adriamycin or bovine serum albumin in the mouse. Nephron 1995, 69(3):293-300

10. Chen A, Sheu LF, Ho YS, Lin YF, Chou WY, Chou TC, Lee WH: Experimental focal segmental glomerulosclerosis in mice. Nephron 1998, 78(4):440-452.

11. Deman A, Ceyssens B, Pauwels M, Zhang J, Houte KV, Verbeelen D, Van den Branden C: Altered antioxidant defence in a mouse adriamycin model of glomerulosclerosis. Nephrol Dial Transplant 2001, 16(1):147-150.

12. Oteki T, Nagase S, Shimohata H, Hirayama A, Ueda A, Yokoyama H, Yoshimura T: Nitric oxide protection against adriamycin-induced tubulointerstitial injury. Free Radic Res 2008, 42(2):154-161.

13. Guo J, Ananthakrishnan R, Qu W, Lu Y, Reiniger N, Zeng S, Ma W, Rosario R, Yan SF, Ramasamy R, et al: RAGE mediates podocyte injury in adriamycininduced glomerulosclerosis. J Am Soc Nephrol 2008, 19(5):961-972.

14. Koshikawa M, Mukoyama M, Mori K, Suganami T, Sawai K, Yoshioka T, Nagae T, Yokoi H, Kawachi H, Shimizu F, et al: Role of p38 mitogenactivated protein kinase activation in podocyte injury and proteinuria in experimental nephrotic syndrome. J Am Soc Nephrol 2005, 16(9):2690-2701

15. Shioji K, Kishimoto C, Nakamura H, Masutani H, Yuan Z, Oka S, Yodoi J: Overexpression of thioredoxin-1 in transgenic mice attenuates adriamycin-induced cardiotoxicity. Circulation 2002, 106(11):1403-1409.

16. Kobayashi M, Sugiyama H, Wang DH, Toda N, Maeshima Y, Yamasaki Y, Masuoka N, Yamada M, Kira S, Makino H: Catalase deficiency renders remnant kidneys more susceptible to oxidant tissue injury and renal fibrosis in mice. Kidney Int 2005, 68(3):1018-1031.

17. Sunami $R$, Sugiyama $H$, Wang $D H$, Kobayashi M, Maeshima $Y$, Yamasaki $Y$, Masuoka N, Ogawa N, Kira S, Makino H: Acatalasemia sensitizes renal tubular epithelial cells to apoptosis and exacerbates renal fibrosis after unilateral ureteral obstruction. Am J Physiol Renal Physiol 2004, 286(6): F1030-F1038.

18. Kikumoto $Y$, Sugiyama $H$, Inoue $T$, Morinaga $H$, Takiue K, Kitagawa M, Fukuoka N, Saeki M, Maeshima Y, Wang DH, et al: Sensitization to alloxaninduced diabetes and pancreatic cell apoptosis in acatalasemic mice. Biochim Biophys Acta 2010, 1802(2):240-246.

19. Noiri E, Nagano N, Negishi K, Doi K, Miyata S, Abe M, Tanaka T, Okamoto K, Hanafusa $N$, Kondo $Y$, et al: Efficacy of darbepoetin in doxorubicininduced cardiorenal injury in rats. Nephron Exp Nephrol 2006, 104(1): e6-e14.

20. Ikeda Y, Tanaka H, Esaki M: Effects of gestational diethylstilbestrol treatment on male and female gonads during early embryonic development. Endocrinology 2008, 149(8):3970-3979. 
21. Uchida HA, Sugiyama H, Takiue K, Kikumoto $Y$, Inoue T, Makino H: Development of Angiotensin II-induced Abdominal Aortic Aneurysms Is Independent of Catalase in Mice. J Cardiovasc Pharmacol 2011, 58(6):633-638.

22. Noguchi N, Rimbara E, Kato A, Tanaka A, Tokunaga K, Kawai T, Takahashi S, Sasatsu M: Detection of mixed clarithromycin-resistant and -susceptible Helicobacter pylori using nested PCR and direct sequencing of DNA extracted from faeces. J Med Microbiol 2007, 56(Pt 9):1174-1180.

23. Poltorak A, He X, Smirnova I, Liu MY, Van Huffel C, Du X, Birdwell D, Alejos E, Silva M, Galanos C, et al: Defective LPS signaling in $\mathrm{C} 3 \mathrm{H} / \mathrm{HeJ}$ and C57BL/10ScCr mice: mutations in Tlr4 gene. Science 1998, 282(5396):2085-2088.

24. Makino $H$, Sugiyama $H$, Kashihara N: Apoptosis and extracellular matrixcell interactions in kidney disease. Kidney Int Supp/ 2000, 77:S67-S75.

25. Sugiyama H, Kashihara N, Maeshima Y, Okamoto K, Kanao K, Sekikawa T, Makino $\mathrm{H}$ : Regulation of survival and death of mesangial cells by extracellular matrix. Kidney Int 1998, 54(4):1188-1196.

26. Zheng Z, Pavlidis P, Chua S, D'Agati VD, Gharavi AG: An ancestral haplotype defines susceptibility to doxorubicin nephropathy in the laboratory mouse. J Am Soc Nephrol 2006, 17(7):1796-1800

27. Pippin JW, Brinkkoetter PT, Cormack-Aboud FC, Durvasula RV, Hauser PV, Kowalewska J, Krofft RD, Logar CM, Marshall CB, Ohse T, et al: Inducible rodent models of acquired podocyte diseases. Am J Physiol Renal Physiol 2009, 296(2):F213-F229

28. Zheng Z, Schmidt-Ott KM, Chua S, Foster KA, Frankel RZ, Pavlidis P, Barasch J, D'Agati VD, Gharavi AG: A Mendelian locus on chromosome 16 determines susceptibility to doxorubicin nephropathy in the mouse. Proc Natl Acad Sci USA 2005, 102(7):2502-2507.

29. Anders HJ, Banas B, Schlondorff D: Signaling danger: toll-like receptors and their potential roles in kidney disease. J Am Soc Nephrol 2004, 15(4):854-867.

30. Brideau G, Doucet A: Over-expression of adenosine deaminase in mouse podocytes does not reverse puromycin aminonucleoside resistance. BMC Nephrol 2010, 11:15.

31. Wu H, Wang YM, Wang Y, Hu M, Zhang GY, Knight JF, Harris DC, Alexander SI: Depletion of gammadelta T cells exacerbates murine adriamycin nephropathy. J Am Soc Nephrol 2007, 18(4):1180-1189.

32. Turnberg D, Lewis M, Moss J, Xu Y, Botto M, Cook HT: Complement activation contributes to both glomerular and tubulointerstitial damage in adriamycin nephropathy in mice. J Immunol 2006, 177(6):4094-4102.

33. Odajima N, Betsuyaku T, Nagai K, Moriyama C, Wang DH, Takigawa T, Ogino K, Nishimura M: The role of catalase in pulmonary fibrosis. Respir Res 2010, 11:183.

34. Fukuoka $N$, Sugiyama $H$, Inoue $T$, Kikumoto $Y$, Takiue $K$, Morinaga $H$, Nakao K, Maeshima Y, Asanuma M, Wang DH, et al: Increased susceptibility to oxidant-mediated tissue injury and peritoneal fibrosis in acatalasemic mice. Am J Nephrol 2008, 28(4):661-668.

35. Godin N, Liu F, Lau GJ, Brezniceanu ML, Chenier I, Filep JG, Ingelfinger JR, Zhang SL, Chan JS: Catalase overexpression prevents hypertension and tubular apoptosis in angiotensinogen transgenic mice. Kidney Int 2010, 77(12):1086-1097.

36. Injac R, Boskovic M, Perse M, Koprivec-Furlan E, Cerar A, Djordjevic A, Strukelj B: Acute doxorubicin nephrotoxicity in rats with malignant neoplasm can be successfully treated with fullerenol $\mathrm{C} 60(\mathrm{OH}) 24$ via suppression of oxidative stress. Pharmacol Rep 2008, 60(5):742-749.

37. Sheerin NS, Risley P, Abe K, Tang Z, Wong W, Lin T, Sacks SH: Synthesis of complement protein $\mathrm{C} 3$ in the kidney is an important mediator of local tissue injury. FASEB J 2008, 22(4):1065-1072.

38. Morelli D, Menard S, Colnaghi MI, Balsari A: Oral administration of antidoxorubicin monoclonal antibody prevents chemotherapy-induced gastrointestinal toxicity in mice. Cancer Res 1996, 56(9):2082-2085.

39. Goth L, Eaton JW: Hereditary catalase deficiencies and increased risk of diabetes. Lancet 2000, 356(9244):1820-1821

40. Moroni G, Novembrino C, Quaglini S, De Giuseppe R, Gallelli B, Uva V, Montanari $\mathrm{V}$, Messa $\mathrm{P}$, Bamonti F: Oxidative stress and homocysteine metabolism in patients with lupus nephritis. Lupus 2010, 19(1):65-72.

41. Makino H, Sugiyama H, Yamasaki Y, Maeshima Y, Wada J, Kashihara N: Glomerular cell apoptosis in human lupus nephritis. Virchows Arch 2003, 443(1):67-77.

42. Erkan E, Garcia CD, Patterson LT, Mishra J, Mitsnefes MM, Kaskel FJ, Devarajan P: Induction of renal tubular cell apoptosis in focal segmental glomerulosclerosis: roles of proteinuria and Fas-dependent pathways. $J$ Am Soc Nephrol 2005, 16(2):398-407.

\section{Pre-publication history}

The pre-publication history for this paper can be accessed here: http://www.biomedcentral.com/1471-2369/13/14/prepub

doi:10.1186/1471-2369-13-14

Cite this article as: Takiue et al:: Acatalasemic mice are mildly susceptible to adriamycin nephropathy and exhibit increased albuminuria and glomerulosclerosis. BMC Nephrology 2012 13:14.

\section{Submit your next manuscript to BioMed Central and take full advantage of:}

- Convenient online submission

- Thorough peer review

- No space constraints or color figure charges

- Immediate publication on acceptance

- Inclusion in PubMed, CAS, Scopus and Google Scholar

- Research which is freely available for redistribution

Submit your manuscript at www.biomedcentral.com/submit 